\title{
6 Constitutional conservatism, anti-democratic ideology, and the elective principle in British North America's upper legislative houses, 1848-1867
}

\author{
Colin Grittner
}

\section{Introduction}

Before Canada emerged as a nation-state in 1867, the former British North America consisted of a series of independent colonies each with its own bicameral legislature. These legislatures consisted of a lower house, or Legislative Assembly, elected by 'the people' and an upper house, or Legislative Council, appointed by its lieutenant governor. Much like their equivalents in Belgium and the Netherlands, these Legislative Councils originally served to curb democratic excess and defend landed interests, roles they filled through 1848 and the advent of responsible government. In Canada, responsible government refers to a parliamentary system where the governor's Executive Council (better known today as the prime minister and his cabinet) both sits within Parliament and finds itself responsible to the parliamentary majority. Under the responsible regime, colonial premiers as leaders of both the Executive Councils and their own political parties - now instructed governors directly as to who should receive appointments to the upper houses. As a result, Legislative Councillors became responsible solely to the political party leaders who appointed them to their positions. For those who preferred the former colonial constitutions, constitutional government had become party government, and narrow party interests had replaced collective group interests. In the many-fronted battle for (and against) popular sovereignty - a battle that crossed social, cultural, economic, and more straightforwardly political lines another check had seemingly fallen as the push toward democratization increased.

In 1849, the year following responsible government, calls rang out anew for elective Legislative Councils. By 1859, the assemblies of the colonies of Canada (now the provinces of Ontario and Quebec), New Brunswick, Nova Scotia, and Prince Edward Island had all endorsed the idea in principle. While only Canada and Prince Edward Island would actually make their upper houses elected, the pursuit of the elective principle across British North America generally unfolded around the same ideological positions. Self-declared radicals and republicans, at one extreme, wanted elective institutions spread as widely as possible. Uncompromising Tories at the other scoffed at anything that did not mirror the British House of Lords. Between these two poles lay the true contest over the colonial 
upper houses. As reformers defended the responsible system they had so recently won, a new conservatism, I argue, formed in the wake of responsible government: one that still favoured the old mixed constitution of Crown, Lords, and Commons but looked to direct election to restore its former essence. These conservatives in particular pressed for elective Legislative Councils - accompanied by strict property qualifications for electors or candidates - in hopes of restoring political legitimacy to their upper houses, siphoning power from the people's assemblies and ultimately undercutting responsible government itself. Much like the Dutch, Swedish, and Danish conservatives seen elsewhere in this volume, British North American conservatives had thus looked to stifle the spread of democracy through elective institutions normally associated with democracy itself.

\section{Historiography}

Within Canadian historiography, discussions of British North America's elective Legislative Councils trace back to the earliest days of Canadian history as a profession. These early histories reflect institutional studies in their purest sense, where analyses took place within narrow provincial frameworks and ideas of expediency and partisanship dominated explanations for change (Harvey 1922; Mackay 1963; McArthur 1930; Hart 1960; Beck 1957; MacNutt 1960). Since the turn of the twenty-first century, provincial emphases have changed little when it comes to British North America's upper houses, and only the Canadian Legislative Council has received any recent attention. Even so, intellectual historians and political scientists, such as Jeffrey McNairn and David E. Smith, have done much to revitalise the subject through a deeper understanding of eighteenth- and nineteenth-century political thought. Both authors, writing concurrently, have claimed very much the same thing: that a dialectic between republicanism and conservatism gave rise to the Province of Canada's elected Legislative Council during the 1850s.

Within the British North American context, historians have tended to most closely associate republicanism with the Canadian Rebellions of 1837 and 1838. In response to perceived oligarchic rule, French-speaking Lower Canadians in particular turned to republican ideas of popular sovereignty to empower themselves as a provincial majority (Ducharme 2014b). As part of their famed NinetyTwo Resolutions of 1834, these so-called patriotes repeatedly demanded an elective Legislative Council so they might fully realise republican rule (Lower Canada 1834). The Imperial government's rejection of these Resolutions in 1837 ultimately led to open rebellion that autumn (Ducharme 2014b). Canadian conservatives, in their active support of the Imperial government, vehemently disassociated themselves from the patriote cause. Yet Canadian conservatives would also come to pursue an elective upper house less than twenty years later.

Acknowledging this situation, McNairn and Smith argue that these conservatives had a different example in mind when they pursued the elective principle: that of the republican United States. McNairn, for his part, emphasises the template offered by American Federalist thought. Responding to post-revolutionary political instability, the Federalists crafted an American federal constitution in 
1787 that established separations of powers resting 'squarely on popular sovereignty, but that still encapsulated the benefits of the three classical forms of government [King, Lords, and Commons]' (McNairn 1996, p. 508). McNairn concludes that these conservative checks upon democratic excess served as a model for Canadian reformulations of the Legislative Council (McNairn 2000). While Smith ultimately agrees with McNairn in principle, he questions some of the details. The American Senate, as established by the federal constitution, would not operate electively until 1913. With this in mind, Smith argues that American state constitutions provided Canadian conservatives with working models for successfully balanced separations of powers. Just as elected state senates served as important and respected checks within state legislatures, an elective Legislative Council could fill the same role for Canada. Through this decision, Smith concludes that 'Canadians came closer than at any time in their history to facing the republican option' (Smith 1999, pp. 87-89).

While this chapter does not seek to contradict McNairn or Smith on these general points, it does take a closer look at the elective bodies that British North American conservatives hoped to establish. By 1855, all but three American states had eliminated the property qualifications on their state franchises (Keyssar 2000). These state franchises - grounded in republican ideals of white male equality and popular sovereignty - governed all state elections, including those for state senators (Scalia 1999). While British North American conservatives may have pursued the elective principle, they fundamentally resisted any broader application of republican government. Anything that approached universal manhood suffrage was viewed as anathema for the elective Legislative Councils. If British North America's lower houses served the people, its upper houses, according to these conservatives, needed to return to their original purpose and serve landed interests. The elective principle and restrictive property qualifications - for electors, candidates, or both offered British North American conservatives a means to achieve this goal and restore the constitutions that responsible government had so recently unbalanced.

\section{Responsible government and the elective principle}

With this background in place, the story of British North America's elective Legislative Councils begins in earnest on 25 April 1849. The Canadian governor general, Lord Elgin, had just signed the so-called Rebellion Losses Bill into law, and in response, an angry Tory mob torched the market building that housed Canada's Parliament. Throughout the 1840 s, Canadian conservatives had warned Elgin that responsible government would open the door to destructive legislation based upon selfish party interests (Fuimus 1847). To conservative eyes, Canada's Reform government had just endorsed the most unjust and self-serving party legislation imaginable. In the name of provincial reconciliation, the Rebellion Losses Bill compensated anyone who had lost property during the Lower Canadian Rebellions of 1837 and 1838, including those who had taken up arms against the Crown (Province of Canada 1849; cf. Careless 1967). Most of those who supported the uprisings now sided with the Reform cause. The Reform government 
had to stack the upper house with multiple new members just to get the legislation to pass (British American League 1849a). For conservatives, the Rebellion Losses Bill had proven that the constitutional checks formerly offered by the Legislative Council no longer applied under responsible government. The Parliament building, now burning in the darkness, served as direct evidence of what might continue to happen without those former checks restored.

Canada's Rebellion Losses controversy offered the initial push for British North American conservatives towards elected Legislative Councils. As one historian notes, Canadian conservatives of all stripes responded to the legislation 'by organising Constitutional Societies to promote conservative policy' (Way 1995, p. 20). The largest of these societies, the British American League, formed in the days preceding Lord Elgin's fateful trip to Parliament. The League's purpose was twofold: first, to determine whether Canada should break its imperial connection to Great Britain; and second, to figure out how to restore political legitimacy to the province's Legislative Council (Allin 1915). On the first point, League members agreed: Canada would remain loyal. On the second point, opinions were much more divided. Some delegates, on the one hand, viewed it as 'essential to the interests and liberties of the people [. . . ] that the Legislative Council should be elected'. For them, an elected upper house, when combined with strict qualifications for either candidates or voters, 'would be virtually and in fact a much more conservative body than we have at present' (British American League 1849a, pp. 7-8; British American League 1849b, app.xxv). Older Tories, on the other hand, balked at any mention of reform whatsoever and worked to preserve existing constitutional arrangements. The question ultimately proved so contentious that the League's general convention refused to discuss it further and instead referred it to the League's local branches (British American League 1849b). Answers trickled in soon enough. By January 1850, the majority of League associations had voted in favour of an elective upper house (Toronto Independent 1850).

The British American League never held another general convention to ratify these local results. The question of elective Legislative Councils had laid bare the ideological divisions between its two schools of conservatives. Although a majority of branches had endorsed the elective principle, the League's sizeable Tory component refused to accept the outcome. A letter from J. W. Gamble to the members of the Yorkville (Toronto) branch reveals the extent of those divisions. Gamble, a leading Leaguer from the Toronto area, supported the elective principle wholeheartedly. The Yorkville branch had not only disagreed with Gamble's position but had done so publicly, personally, and confrontationally. In Gamble's own words:

It is with much concern that I have read [. . .] a resolution passed by you in reference to my views on the question of elective institutions. [. . . [P] assing over the direct personal allusion to myself, [. . .] I submit whether any advantage to be derived from parading before the public merely conflicting opinions of members of an association, whose utility depends upon its unanimity, and whose measures, to carry weight with them, must be based upon some show of reason and sound sense, is not more than doubtful.

(Gamble 1850) 
Older Tories used such direct tactics alongside their broader colonial influence to forestall any further assemblies (Allin 1915). Without a mandate, the League's executive formally pursued the subject no further. Its public address of May 1850 made no mention of the Legislative Council whatsoever (Toronto British Colonist 1850).

The League's public silence, however, did not prevent its message from finding a wider audience. As part of its efforts to promote conservative policy, the British American League made repeated entreaties to potential sympathisers across British North America's Maritime colonies. League delegates, for instance, met with John Robertson and Charles Simonds of the New Brunswick Colonial Association in October 1849 (MacNutt 1960). These two groups agreed to meet again in Halifax to discuss, among other things, Legislative Councils and a broader union of the colonies. Persuaded by their Canadian counterparts, the New Brunswick Colonial Association would soon enough promote the elective principle for their own upper house as well (Toronto North American 1850). League delegates, moreover, sent out personal letters to 'prominent and influential citizens in Halifax' and circulated pamphlets within Maritime urban centres (Toronto Independent 1849). They also ensured to keep the Maritime press well informed. Newspapers throughout the eastern colonies highlighted the League, its conventions, and the arguments of its delegates. Maritime editors kept a keen eye on the idea of an elective upper house, whether they supported it or not (Fredericton Head Quarters 1849, 1850; Halifax British Colonist 1849a, 1849b, 1850a, 1850b).

Despite these apparent successes elsewhere, the British American League would not survive into 1851 . The elective principle had torn it into two warring camps. The League's broader reaction against responsible government and its rejuvenated brand of conservatism had nonetheless travelled across British North America. These ideas, including elective Legislative Councils, would soon worm their way into colonial legislatures. From there, they would take on lives of their own.

\section{Conservative legislation and the elective principle}

In this regard, conservatives from Nova Scotia picked up the torch first. Responsible government, according to Nova Scotia's leading conservative, J. W. Johnston, had 'placed the Local affairs of the Province in the hands of the Executive Council unrestrained by any control on the part of the Lieutenant Governor or the Imperial Government' (Johnston 1850, p. 5). Executive oligarchy and party interests now reigned supreme. The 'Canadian Rebellion Reward Bill', as Johnston called it, had proven that the upper branches of government could no longer curtail unjust legislation under the responsible system. In Nova Scotia as well, Johnston saw the province's new Reform government acting in ways that sowed the same discordant seeds. Despite imperial policy, the new executive had dismissed one hundred Nova Scotian magistrates without cause or explanation, only to appoint 250 replacements. Reformers now sat on county benches across the province with friendship serving as their primary qualification (Johnston 1850, pp. 6-8; cf. Halifax British Colonist 1849c). Nova Scotia's new Reform executive had thus revealed an apparent willingness to exploit responsible government even 
at the expense of local justice. Propelled by these concerns - alongside Prime Minister Lord John Russell's recent acceptance of an elective upper house for the Cape Colony in South Africa - Johnston read a series of sweeping resolutions to Nova Scotia's House of Assembly, headlined by 'the Election of the Legislative Council by the people' (Johnston 1850, p. 5; cf. Wight 1947, pp. 71-72). Johnston argued that only an elective upper house would break executive dependency and 'weaken those influences that result in merely party adhesions' (Johnston 1850, p. 5; cf. Nova Scotia 1850, pp. 565, 569). Johnston's conservative resolution for an elective Legislative Council signalled the first of its kind in British North America's history.

Johnston, in the end, failed in this initial resolution. A similar motion failed within Nova Scotia's upper house as well (Halifax British Colonist 1850c, 1850d, $1850 \mathrm{e}, 1850 \mathrm{f})$. The province's Reform majority, having just secured responsible government, aligned against any constitutional change that might jeopardise its continued survival (Nova Scotia 1850, pp. 602-605). Even so, the idea of elective Legislative Councils gathered steam within British North American conservative circles. By March of 1850, Prince Edward Island conservatives had also given notice 'to render the Legislative Council ELECTIVE' based upon the belief that only an elected upper house would be "truly "responsible" and useful to the public' (Charlottetown Islander 1850). Unfortunately for these conservatives, their motion died when the legislative session ended. From May to August of the same year, the Canadian Legislative Assembly also heard a total of four conservative motions for an elective upper house based upon similar arguments (Province of Canada 1850, pp. 17-18, 40, 91-94, 245). These motions also failed as well when Canada's Reform majority sided against them as threats to responsible government.

In New Brunswick, however, a conservative coalition government held power. Much like their compatriots elsewhere in British North America, New Brunswick conservatives also believed that

[t]he extension of the principle of self-government has so increased the power of the House of Assembly over the Legislative Council [. . .] that the Legislative Council does not now retain the constitutional check which that Branch is called upon to exercise according to the theory of our mixed form of Government.

Seizing on the Imperial government's promise to the Cape Colony, these conservatives formally proposed an elective Legislative Council for New Brunswick so 'as to secure a more perfect constitutional balance [. . . ] than any other attainable in the present state of Colonial Society' (New Brunswick 1850, pp. 348-349). The proposal received the Assembly's formal approval in April of 1850 and the colonial secretary's attention the following November. After some delay, New Brunswick obtained its reply in mid-February of 1851. The Imperial Government had no objection to an elected Legislative Council so long as it came with restrictive property qualifications attached for either electors or candidates (New Brunswick 
1851a, p. 42). Such a decision had far-reaching implications. Not only had New Brunswickers obtained permission for an elective upper house but British North America's opponents to responsible government had also received the precedent they needed. If these conservatives wanted to restore legitimacy and power to their Legislative Councils, the Colonial Office accepted the elective principle so long as restrictive qualifications arrived alongside.

While New Brunswickers had obtained permission for an elective Legislative Council first, their pursuit of the principle ultimately went no further. When confronted with elective legislation tabled within New Brunswick's upper house in February of 1851, the province's Legislative Councillors themselves saw no reason as to why they should stoop to running for their offices (New Brunswick 1851 b, pp. 62, 119). The majority of these Councillors believed that the Legislative Council had

hitherto performed its function with every consideration of the public interest; and while preventing on the one hand improvident expenditure, hasty and imprudent legislation, it has on the other carefully avoided all captious or factious opposition to any well digested measure.

Because New Brunswick's Legislative Councillors reportedly continued to perform their customary duties, these same Councillors concluded that 'the Country is not prepared for, nor favourable to, such an organic change in the constitution of this Province' (New Brunswick 1851b, pp. 164-165). As a result of this intransigence, New Brunswick would retain an appointed Legislative Council for as long as it kept an upper chamber (Campbell 2007).

Nova Scotia, on the other hand, would come much closer to making its Legislative Council elected. Beginning in 1852, Nova Scotia's conservative legislators pushed elective legislation by adapting the language of democratic reform to a conservative's view of the British mixed constitution. According to J. W. Johnston, the elective principle was 'a step in advance' not only because it gave Nova Scotians 'the power of choosing their own law-givers' but also because it '[gave] to our constitution that stability without which any constitution is worth but little' (Halifax British Colonist 1852a, 1852b). Stability, here, would come through constitutional balance, and constitutional balance, in turn, would come through property. The House of Assembly had just replaced its property-based franchise with a ratepayers' franchise the previous year (Nova Scotia 1851). The latter's inclusiveness meant that the province's lower house now spoke for the people more than ever before. An elective Legislative Council, according to conservatives like Johnston, needed clear property qualifications to ensure the people's voice did not overwhelm any further those of property and wealth. Johnston's own suggestions looked to put these beliefs into practice. According to Johnston's original formulation, voters at Legislative Council elections would have had to possess real estate worth at least $£ 100$ and have it registered at least six months prior to an election. Candidates, conversely, would have needed to possess ten times that amount of real property - at least $£ 1,000$ worth - and have held the status of 
British subject for at least thirty years. While Johnston eventually reduced these qualifications, he still ensured to foreground real property so 'as to preclude cavil or opposition from any, no matter how conservative in principle' (Halifax British Colonist 1852a). It would take some time, but these resolutions eventually came to vote in 1858 once Johnston and his Conservative party formed government.

Because of the Conservative strategy, the province's Liberal opposition had tremendous difficulty coordinating its response. On the one hand, some viewed the legislation as radical insofar as they believed it 'the duty of the Crown officers to preserve the form of government [...] and not to impose on us such a ridiculous hybrid, mongrel sort of constitution' (Nova Scotia 1858, p. 105). Conversely, other Liberals viewed an elective Legislative Council as intrinsically, even dangerously, conservative because it would 'strike a fatal blow at the [responsible] system of government' by eventually 'denud[ing] [the House of Assembly] of all real practical power'. More specifically, they worried that Johnston's proposed 'superior franchise' for Legislative Council elections would 'strike a death blow to the power of [the lower house]' in terms of its control over public spending (Nova Scotia 1858, pp. 107-108). These Liberals feared that a newly reinvigorated upper house - governed by higher franchise and candidacy qualifications could legitimately claim to represent the property and wealth of Nova Scotia. An elected legislative body that represented a province's wealth theoretically had greater claim to dictate how government spent that wealth. Control over revenues could then conceivably shift from the lower house to the upper, thereby stripping the Assembly of its greatest privilege and taking the power of the purse from the people's hands. Although it may have appeared as radical, Johnston's game was about as conservative as it got. In the end, Nova Scotia's elective Legislative Council legislation deadlocked the Assembly, twenty-six to twenty-six. Johnston, as Conservative party leader, refused to pursue the legislation without a clear majority (Halifax British Colonist 1858). Soon enough, the Conservative fell from office, and Johnston retired from legislative politics. Nova Scotia's window for an elected upper house had ultimately closed for good.

New Brunswick and Nova Scotia would never have elective Legislative Councils despite the precedents they had set. Conservative arguments for constitutional balance and legislative legitimacy could not sway enough people to pursue further changes to responsible government. Those same arguments, however, had different effects in the Province of Canada and Prince Edward Island. In Canada, radical demands for widespread elective institutions had merged with a growing conservative acceptance of elective upper houses by the early 1850 s. While these radicals had proposed qualifications actually lower than those for the Legislative Assembly, Canada's conservatives had something else in mind. As conservatives gained further power within the Assembly between 1852 and 1856, candidacy qualifications proposed for elected Legislative Councillors swelled from mere residency to $£ 1,000$ worth of unencumbered real property to $£ 2,000$ worth of unencumbered real property (Province of Canada 1852b, p. 197; Province of Canada 1853, p. 924; Province of Canada 1856b, p. 212). Even wealthy professionals in Canada's largest cities may not have held estates so large. Indeed, 
George-Étienne Cartier - one of Montreal's most prominent lawyers and attorney general for Canada East from 1858 to 1862 - had paid only $£ 1,600$ for his wellappointed three-storey residence in downtown Montreal (Young 1981).

As these qualifications increased, Canada West's leading reformer, George Brown, looked on in horror. Just like reformers in Nova Scotia, Brown railed against an elected Legislative Council because, in his own words:

It is a Tory measure [...] and will be resisted by every man who truly favours the cause of progression. [. . . In this country it emanated from the Tory league, and in Nova Scotia it was submitted to Parliament by the Tory Attorney General, Mr. Johnston, and resisted by the progressive party on the ground that it was destructive to responsible government, that bane of Toryism.

(Province of Canada 1852a, pp. 1105-1107)

Brown continued his attack outside Parliament through his newspaper, the Toronto Globe. Simultaneously enraged and mystified, he asked his readers:

would this second elective chamber destroy Responsible Government? Of course it would. [. . .] We can understand the heat of the Tories, - we cannot understand the haste of Reformers to pull down a Constitution which gives them full and direct power. After fighting thirty years to obtain a position, and finding it to realize all our expectations - shall we fling it away without one solid complaint, to run after a theory?

(Toronto Globe 1852)

As he reflected on these questions, Brown ultimately arrived at the conclusion that '[i]nstead of advancing in liberal opinions we are going back - instead of the control of the public will being more direct it is more remote' (Toronto Globe 1853). Despite Brown's warnings against further constitutional change, Canadian radicals united with the province's Conservatives in 1856 to establish British North America's first elective Legislative Council. The legislation required future Councillors to possess in fee simple the aforementioned £2,000 worth of real property (Province of Canada 1856a). As Canada's wealthiest inhabitants took their seats within the Legislative Council, they found themselves well placed to defend the interests of accumulated wealth. The people already had their house; the province's landed interests could once again claim theirs.

With the Canadian precedent emerging before them, Prince Edward Island's conservatives now made their final push for an elective Legislative Council as well. By 1859, Island voters had returned their Conservative party to power. In the meantime, public meetings across the Island demanded an elective Legislative Council to better realise 'true' responsible government (Charlottetown Islander 1858). By 1861, Island Conservatives had engineered enough support in both legislative houses to get elective legislation passed (Charlottetown Examiner 1860a, $1860 \mathrm{~b}, 1860 \mathrm{c})$. The legislation's final form, however, emerged at the behest of the new colonial secretary, the duke of Newcastle. Instead of property qualifications 


\section{0}

for candidates, Newcastle preferred property qualifications for electors, which the government ultimately pegged at $£ 100$ of real property (Prince Edward Island 1862). Unlike in the Province of Canada, where property qualifications remained the basis for electoral enfranchisement, Prince Edward Island had linked its franchise to the performance of statute labour in 1853 (something Island men had to perform anyway) (Prince Edward Island 1853; Grittner 2012). Such a franchise had pushed colonial governance even further towards male participatory democracy. An elective Legislative Council, elected solely by property holders, promised to roll back this democratic advance and give Island proprietors a much stronger political voice (Charlottetown Islander 1863). Through the elective principle, the Island's landed elite had thus wrested back its house. As Legislative Councillors returned to their traditional position as propertied mediators between the people and the Crown, the question soon became, how would they use that position once they took their seats?

\section{Elective legislative councils in principle and in practice}

Canada's leading nineteenth-century conservative and first prime minister, John A. Macdonald, once pronounced that upper houses needed to represent property because ' $[t]$ he rights of minority must be protected, and the rich are always fewer in number than the poor' (Browne 2009, p. 98). Colonial conservatives like Macdonald had turned to elective Legislative Councils following responsible government in an attempt to put this idea into practice and limit democratic influence across British North America. Through the political legitimacy offered by direct election, British North America's upper houses could have conceivably gained the ability to not only stand up to the people's assemblies but also usurp their power (thereby undercutting responsible government itself). Yet these goals ultimately proved easier conceived than accomplished within the British North American setting. In the Province of Canada, the $£ 2,000$ candidacy qualification had drastically limited the pool of potential Councillors because few inhabitants possessed so much property in fee simple. While some constituencies held spirited elections, a full two-thirds of Council seats went uncontested by 1864 (Emery 2012; Hart 1960). The most talented candidates wanted to sit in the Legislative Assembly anyway, alongside their party leaders (Ajzenstat 2003). Canada's elective Legislative Council soon became a halfway house for those who lost their seats in the Assembly. Only '[o]ld men, dead politically or nearly dead physically' sat there by choice (in Shirley Carkner Hart's colourful words) (Hart 1960, p. 207). In 1859, the Legislative Council showed a glimmer of independence when, as a 'co-ordinate and co-equal branch', it refused to pass the annual supply bill that granted public spending (Province of Canada 1859, pp. 421, 438). Such defiance proved fleeting, and supply passed mere days later after some absentees returned and voted along party lines (Province of Canada 1859, p. 468). Canada's Legislative Council would never try anything like it again (Province of Canada 1865, p. 117). Its members, collectively, had neither the ambition nor the acumen to truly stand up to the people's house.

The elective principle similarly failed to rejuvenate the Legislative Council on Prince Edward Island. While some premiers had attempted to lead 
government from the elected upper house, they quickly found themselves overshadowed as colonial finances remained firmly entrenched within the people's assembly. Soon enough, Islanders of all political stripes began to demand the upper chamber's total abolition. Some saw it as a 'useless institution' filled with 'rich noodles' (Charlottetown Examiner 1878a). Others viewed it as 'effete and expensive', wasting \$7,000 per year (Charlottetown Examiner 1878b). Perhaps most important of all, conservatives who had supported the elective principle now derided the Legislative Council as neglectful of its duties. 'These Councillors were put in by the property-holders to look specially after their rights of property, and guard against hasty, oppressive or unjust legislation', one conservative editor declared in 1878. 'Every one of them [. . .] grossly violated the sacred trust reposed in them by carelessly and hastily "piling on the agony" upon the wronged country' by passing unpopular legislation in the form of direct taxes (Charlottetown Presbyterian and Evangelical Protestant Union 1878). The supposedly conservative body had proven far less conservative and far more partisan than hoped. It did not help that judges had interpreted Prince Edward Island's Legislative Council franchise incredibly broadly. Besides freeholders and leaseholders, squatters also voted at Legislative Council elections so long as they squatted on $£ 100$ (or \$325) worth of land (Public Archives and Record Office of Prince Edward Island 1877-8). Such electors certainly did not represent the Island's landholding elite.

Prince Edward Island's elective Legislative Council would limp on through to 1893 . Islanders ultimately recognised that they had too much government for such a small province and amalgamated their two houses into one (Harvey 1922; Kennedy 1997). By then, Canada's elective Legislative Council was long dead. The new provinces of Quebec and Ontario had rejected the elective principle at Confederation in 1867. Quebec returned to an appointed upper house, while Ontario abolished its upper house altogether. The new Dominion of Canada, with its capital in Ottawa, would also resort to an appointed Senate upon its creation in 1867. The elective principle had clearly disappointed its previous adherents (Ajzenstat 2003). It had not rebalanced the British North American constitutions, as promised; it had not waged war for landed interests; and it had not undercut responsible government. By the time legislators debated Canadian Confederation in 1864 and 1865, even John A. Macdonald showed little enthusiasm for the elective principle (Province of Canada 1865, p. 35). Conservatives like Macdonald had come to realise that it was easier to work within the responsible system - and to manipulate it - than to attack it directly through elective institutions (Ducharme 2014a). A weakened upper house, reliant upon government appointments, served shifting strategies in this regard.

\section{References}

Ajzenstat, J. (2003), 'Bicameralism and Canada's founders: The origins of the Canadian Senate', in: Joyal, S. (ed.), Protecting Canadian Democracy: The Senate You Never Knew (Montreal-Kingston: McGill-Queen's University Press), pp. 3-30. 
Allin, C.D. (1915), The British North American League, 1849 (Toronto: The Ontario Historical Society).

Beck, J.M. (1957), The Government of Nova Scotia (Toronto: University of Toronto Press). British American League (1849a), Minutes of the Proceedings of a Convention of Delegates of the British American League, Held at Kingston (Canada West) on the 25th, and Adjournment the 26th, 27th, 28th and 31st Days of July 1849 (Kingston: The Chronicle and News Office).

British American League (1849b), Minutes of the Proceedings of the Second Convention of Delegates of the British American League, Held at Toronto, C. W., on Thursday, November 1, and by Adjournment on the 2nd, 3rd, 5th, 6th and 7th of November 1849 (Toronto: The Patriot Office).

Browne, G.P. (ed.) (2009), 'Hewitt Bernard's notes on the Quebec Conference, 11-25 October, 1864', Documents on the Confederation of British North America: A Compilation Based On Sir Joseph Pope's Confederation Documents Supplemented by other Official Material (Montreal-Kingston: McGill-Queen's University Press), pp. 93-126.

Campbell, G. (2007), 'Defining and redefining democracy: The history of electoral reform in New Brunswick', in: Cross, W. (ed.), Democratic Reform in New Brunswick (Toronto: Canadian Scholars' Press), pp. 273-299.

Careless, J.M.S. (1967), Union of the Canadas: The Growth of Canadian Institutions 1841-1857 (Toronto: McClelland and Stewart).

Charlottetown Examiner (1860a), 'The Legislative Council', 24 April, p. 3.

Charlottetown Examiner (1860b), 'The Swamping of the Legislative Council', 22 May, p. 3.

Charlottetown Examiner (1860c), 'The Swamping of the Council', 12 June, p. 2.

Charlottetown Examiner (1878a), 'Abolition of the Legislative Council', 19 April, p. 1.

Charlottetown Examiner (1878b), 'Legislative Council Elections', 11 October, p. 3.

Charlottetown Islander (1850), 'The Legislative Council', 22 March, p. 3.

Charlottetown Islander (1858), 'Public Meeting at Souris', 12 March, p. 2.

Charlottetown Islander (1863), 'Political Meeting in the Second Elective Legislative Council District', 2 January, p. 2.

Charlottetown Presbyterian and Evangelical Protestant Union (1878), 'The Legislative Council Elections', 7 November, p. 8.

Ducharme, M. (2014a), 'Macdonald and the Concept of Liberty', in: Dutil, P. and Hall, R. (eds.), John A. Macdonald at 200: New Reflections and Legacies (Toronto: Dundurn Press), pp. 141-169.

Ducharme, M. (2014b), The Idea of Liberty in Canada During the Age of Atlantic Revolutions, 1776-1838 [transl. Peter Feldstein] (Montreal-Kingston: McGill-Queen's University Press).

Emery, G. (2012), Elections in Oxford County, 1837-1875: A Case Study of Democracy in Canada West and Early Ontario (Toronto: University of Toronto Press).

Fredericton Head Quarters (1849), 'The Address of the British League', 15 August, p. 2.

Fredericton Head Quarters (1850), 'Editorial', 16 January, p. 3.

Fuimus (1847), Letter to His Excellency the Right Honorable Lord Elgin, on Responsible Government, As applied simply to the Province of Canada; Together with his Lordship's Celebrated Speech, Delivered in the House of Commons, as Lord Bruce, in 1841, Deprecating, in the Strongest Terms, All Appointments to Office by a Tottering Ministry, Not Enjoying the Confidence of the People (Montreal: Donoghue \& Mantz).

Gamble, J.W. (1850), To the Members of the Yorkville Branch of the British American League (Vaughan, ON).

Grittner, C. (2012), 'Working at the crossroads: Statute labour, manliness, and the electoral franchise on Victorian Prince Edward Island', Journal of the Canadian Historical Association 23(1), pp. 101-130. 
Halifax British Colonist (1849a), 'The League', 16 August, p. 2.

Halifax British Colonist (1849b), 'The League', 18 August, p. 2.

Halifax British Colonist (1849c), 'A Greedy Executive', 15 September, p. 2.

Halifax British Colonist (1850a), 'Latest by Telegraph', 12 January, p. 2.

Halifax British Colonist (1850b), 'From Canada', 22 January, p. 2.

Halifax British Colonist (1850c), 'Provincial Legislature. Legislative Council. Question of Elective Council', 16 April, p. 1.

Halifax British Colonist (1850d), 'Provincial Legislature. Legislative Council. Question of Elective Council', 18 April, pp. 1-2.

Halifax British Colonist (1850e), 'Provincial Legislature. Legislative Council. Question of Elective Council', 20 April, pp. 1-2.

Halifax British Colonist (1850f), 'Provincial Legislature. Legislative Council. Question of Elective Council', 25 April, pp. 1-2.

Halifax British Colonist (1852a), 'Provincial Parliament. House of Assembly', 3 February, p. 2.

Halifax British Colonist (1852b), 'Hon. Mr. Johnston's Speech on the Elective Legislative Council Bill - Concluded', 6 March, p. 2.

Halifax British Colonist (1858), 'Editorial', 9 March, p. 2.

Hart, S.E.C. (1960), The Elective Legislative Council in Canada under the Union: Its Role in the Political Scene (MA thesis: Queen's University).

Harvey, D.C. (1922), 'The passing of the second chamber in Prince Edward Island', Report of the Annual Meeting of the Canadian Historical Association 1(1), pp. 22-31.

Johnston, J.W. (1850), Speech Delivered by the Hon. J. W. Johnston, in the House of Assembly, On the 19th March, 1850, on Introducing Resolutions for Defining the Nation and Foundation of the Self-government of Nova Scotia in Her Local Affairs: And in Favor of an Elective Legislative Council (Halifax: The British Colonist).

Kennedy, E. (1997), 'Tabling the legislature: One hundred years of general elections, 1893-1993', Island Magazine 42, pp. 13-24.

Keyssar, A. (2000), The Right to Vote: The Contested History of Democracy in the United States (New York: Basic Books).

Lower Canada (1834), Journals of the House of Assembly of Lower Canada.

Mackay, R.A. (1963), The Unreformed Senate of Canada [3rd rev. edition] (Toronto: McClelland and Stewart).

MacNutt, W.S. (1960), New Brunswick. A History: 1784-1867 (Toronto: Macmillan).

McArthur, D. (1930), 'A Canadian experiment with an elective upper chamber', Proceedings of the Royal Society of Canada 24, 3rd series, section II, pp. 79-88.

McNairn, J.L. (1996), 'Publius of the north: Tory republicanism and the American constitution in Upper Canada, 1848-54', Canadian Historical Review 77(4), pp. 504-537.

McNairn, J.L. (2000), The Capacity to Judge: Public Opinion and Deliberative Democracy in Upper Canada, 1791-1854 (Toronto: University of Toronto Press).

New Brunswick (1850), Journal of the House of Assembly of the Province of New Brunswick.

New Brunswick (1851a), Journal of the House of Assembly of the Province of New Brunswick.

New Brunswick (1851b), Journal of the Legislative Council of the Province of New Brunswick.

Nova Scotia (1850), Journal and Proceedings of the House of Assembly.

Nova Scotia (1851), 'An act to extend the elective franchise', Acts of the General Assembly of the Province of Nova Scotia, 14 Vic., c. 2.

Nova Scotia (1858), The Debates and Proceedings during the Third Session of the TwentyFirst Parliament of the Province of Nova Scotia. 


\section{Colin Grittner}

Prince Edward Island (1853), 'An act to extend the elective franchise', The Acts of the General Assembly of Prince Edward Island, 16 Vic., c. 9.

Prince Edward Island (1862), 'An act to change the constitution of the legislative council, by rendering the same elective', The Acts of the General Assembly of Prince Edward Island, 25 Vic., c. 18.

Province of Canada (1849), 'An Act to provide for the indemnification of parties in LowerCanada whose property was destroyed during the Rebellion in years one thousand eight hundred and thirty-seven, and one thousand eight hundred and thirty-eight', Provincial Statutes of Canada, 12 Vic., c. 58.

Province of Canada (1850), Journals of the Legislative Assembly of the Province of Canada, Vol. 9.

Province of Canada (1852a), Debates of the Legislative Assembly of United Canada, Vol. 11, part 1.

Province of Canada (1852b), Journals of the Legislative Assembly of the Province of Canada, Vol. 11, part 1.

Province of Canada (1853), Journals of the Legislative Assembly of the Province of Canada, Vol. 11, part 2.

Province of Canada (1856a), 'An Act to change the Constitution of the Legislative Council by rendering the same Elective', Statutes of the Province of Canada passed in the Nineteenth and Twentieth Years of the Reign of Her Majesty Queen Victoria and in the Second Session of the Fifth Parliament of Canada, 19 \& 20 Vic., c. 140.

Province of Canada (1856b), Journals of the Legislative Assembly of the Province of Canada, Vol. 14.

Province of Canada (1859), Journals of the Legislative Council of the Province of Canada, Vol. 17.

Province of Canada (1865), Parliamentary Debates on the Subject of the Confederation of the British North American Provinces, 3rd Session, 8th Provincial Parliament of Canada (Quebec: Hunter, Rose \& Co.).

Public Archives and Records Office of Prince Edward Island (1877-8), RG2 Legislative Council fonds, series 2 Election papers, subseries 2, volume 2 'Revision of List of Electors for Second Electoral District for the Legislative Council for King's County.'

Scalia, L.J. (1999), America's Jeffersonian Experiment: Remaking State Constitutions 1820-1850 (DeKalb, IL: Northern Illinois University Press).

Smith, D.E. (1999), The Republican Option in Canada, Past and Present (Toronto: University of Toronto Press).

Toronto British Colonist (1850), 'Address of the Central Committee of the British American League, to their Brethren, Countrymen and Fellow Colonists', 7 May, p. 2.

Toronto Globe (1852), 'An Elective Legislative Council', 13 April, p. 2.

Toronto Globe (1853), 'Elective Legislative Council', 4 June, p. 2.

Toronto Independent (1849), 'New Brunswick on the Canada League and Annexation', 25 October, p. 4.

Toronto Independent (1850), 'Getting on by degrees', 23 January, p. 3.

Toronto North American (1850), 'New Brunswick Colonial Association', 21 June, p. 3.

Way, P. (1995), 'The Canadian tory rebellion of 1849 and the demise of street politics in Toronto', British Journal of Canadian Studies 10(1), pp. 10-30.

Wight, M. (1947), The Development of the Legislative Council 1606-1945 (London: Faber and Faber).

Young, B. (1981), George-Etienne Cartier: Montreal Bourgeois (Montreal-Kingston: McGill-Queen's University Press). 


\section{Eastern Northern America (Canada), c. 1840}

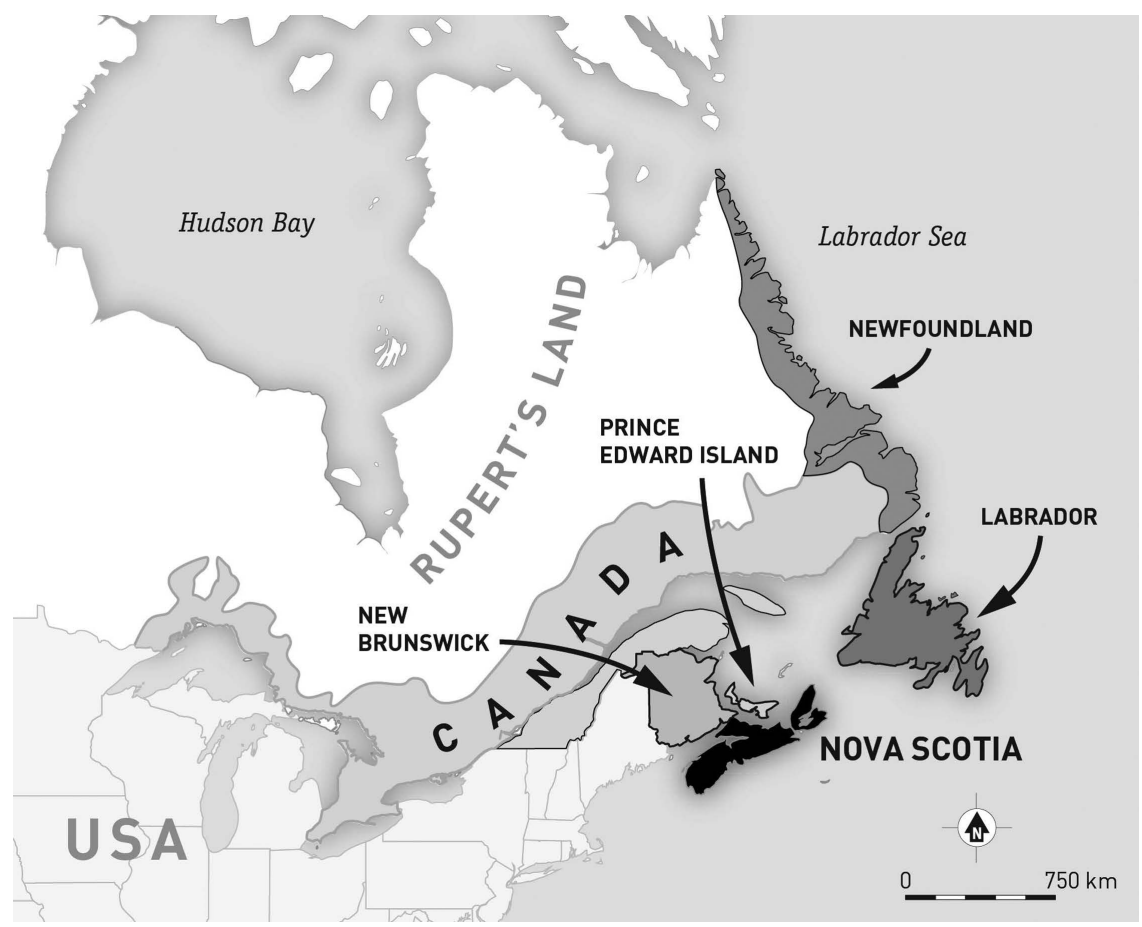

(Bert Brouwenstijn, Vrije Universiteit Amsterdam) 